\section{Ethical Lingua}

Journal of Language Teaching and Literature

ISSN 2355-3448 (Print)

ISSN 2540-9190 (Online)

Volume 4, Number 2, August 2017 pp. $93-108$.

\title{
A Preliminary Exposé of \\ Systemic Functional Theory Fundamentals
}

\author{
Taofeek Olaiwola Dalamu \\ lifegaters@yahoo.com
}

University of Lagos, Nigeria

\author{
Accepted : 1 March 2017 \\ URL : : http://journal.uncp.ac.id/index.php/ethicallingua/article/view/414
}

\begin{abstract}
The study attempted to explain fundamentals of Systemic Functional Theory as textual analytical instruments. The basis was to demonstrate the applications of Ideational, Interpersonal and Textual Metafunctions as alternative semiotic resources that provide composite meaning potential to the structure of the clause. For illustration, six clauses in the advert of Premium Pension Limited were used as textual elements which the three metafunctions were applied. The study revealed conditionality, sensitizationality, judgmentality as well as integrity as the nuggets of the message. In addition, the ad tends to propound solutions to the financial security of the future of the people. The solution is for the recipients to negotiate and begin savings with Premium Pension Limited whose concern is how to care for the people in their old age. Above all, the study concluded that Halliday's theory is a very practicable tool of textual analysis for researchers.
\end{abstract}

Keywords: ideational metafunction, interpersonal metafunction, textual metafunction

\section{Introduction}

In the global terrain, Systemic Functional Theory (henceforth: SFT) is synonymous with Halliday. The academic world, and to be more precise, the linguistics world connects in a massive measure, Halliday with SFT. The claim is manifested through the volumes of the festschrift that have been produced in honor of Michael Alexander Kirkwood Halliday. Most people call him M.A.K. Halliday (henceforth: Halliday). Halliday's series of festschrift record magnanimous success that as of 1996 fifty seven volumes have been produced. And as of 2016, the account has skyrocketed to high heavens under so many headings and subheadings. One among the forms is Advances in Discourse Processes with a subheading Meaning and Choice in Language: Studies of Michael Halliday, Volume LVII. The series of volumes demonstrate the importance of Halliday's impactful ideas and his remarkable contributions to the 
field of linguistics. The volumes also reveal how Halliday's insights have triggered and awakened scholars in linguistics and other fields of study to begin new areas of invention that are thirsting for developments. To the author, Halliday's perspicuous thoughts are a renaissance in a way, perhaps, in the entire academic world. Its encomium is spelt out in that sense thus 'Not many scholars deserve let alone receive - five volumes of festschrift. Michael Halliday does and, when the present volume is finally placed in his hands, he will have achieved yet another rare - and richly deserved - distinction' (Berry, Butler, Fawcett \& Huang, 1996, p. xv).

To a considerable length, it is probable that there is no any other scholar in the current dispensation that has received the large numbers of festschrift written for Halliday. These are academic arguments and appraisals that are still ongoing largely for the growth of SFT in terms of conceptual developments and applications. The efforts witness to a wide acceptance and usefulness of SFT. For the purpose of clarity, many other titles are synonymous with SFT. These are: Systemic Functional Grammar, Systemic Functional Linguistics and Systemic Functional Grammatics. Any of the four labels can be used to represent Halliday's theoretical model. The term Grammatics, to Halliday and Matthiessen, emanates from the way Physics, Mathematics, Geophysics, etc. become lively. Grammatics is coined as a representation of an embodiment of rules that govern grammar and those analytical tools that are propounded to analyze linguistic elements of language. It is meant to maintain the distinction between grammar and theories of grammar (Halliday \& Matthiessen, 1997, p. 15). Concisely, Grammatics in the functional grammar denotes Theory.

Language is a phenomenon that functions at the core of all human activities. It is the essence of humanity (Chomsky, 1972). The complexity of human beings and their activities informs the multi-dimension experience in language analysis. Recapitulating the characteristics of language indicates language manifesting as sound, social, productive, arbitrary, systemic, systematic, rule-governed, culturally human, etc. These could have motivated the projection of SFT in its richness as a meaning-making resource and an appliance for elucidating language functional varieties. It then becomes an unprofitable venture to pin the applications of SFT down to a particular domain of operation. SFT is an openended theoretical model that is strong in textual analysis (Kress \& Leuween, 1996; Fontaine, 2013). Its heuricticity is felt and discussed in language explications regarding text generations and applications. It grows thus far because language itself is a growing phenomenon. In the growing spheres, the applications of SFT, among others, have been discussed in many influential domains. These include communication linguistics, medicine, judicial system and disjunctive systems (e.g. Leech, 1966; Nwinlaaru \& Xuan, 2016). It is also applicable in graphic design (e.g. Kress \& van Leeuwen, 1996), computerization (e.g. Cross, 1992; Kasper, 1988), and casual conversation (e.g. Eggins \& Slade, 1997).

SFT is very useful in processing anthropological data, literary history and intertextual matters (e.g. Lemke, 1995), socio-cognitive and semiotic of art (e.g. O'Toole, 1994), discourse pragmatics and grammatics (McDonald, 1990; Matthiessen, 1995). Experts in children language development (e.g. Painter, 
1984), classroom interaction and learning (e.g. Christie \& Unsworth, 2000), foreign language development (e.g. McGregor, 1990; Olivares, 2013) appreciate the influence of the theory. Significantly, critical discourse analysis, literature and stylistics (e.g. Daramola, 2008) are part of the areas that SFT appropriately functions. This study aims at expanding the growing body of literature in SFT. It explains the applications of the three metafunctional traid to a piece of advertising that Premium Pension Limited (PPL) propagates to the public as a persuasive strategy of patronization. The study characterizes the operations of the Ideational, Interpersonal and Textual Metafunctions in the ad from both its systemic and structural perspectives. This provides a preliminary understanding of the grammatics and its applications.

\section{Literature Review}

\section{SFT: Historical Background}

Ignoring the contributory efforts of past and earlier scholars from the current level of linguistic knowledge is not only deleterious to scholarship; it is a way of forgetting one's original source. Such an attempt can uproot the scholarly pillars in which the current state of knowledge is erected and stabilized. Scholarly acumen has a source. No matter the uniqueness of a conceptual discernment it can possibly be traced to a historical past (De Beaugrande, 1991). The freshness, evolvement and evolution of a theory can be likened to the birth of a new born baby through parents - a father and a mother. It means that every theory has parents and SFT operates in a similar circle. SFT is matchless, yet, it is not eluded from its parents. Some of Halliday's linguistic parents are Firth, Malinowski and Jakobson (Martin, 2016). And Halliday is not in any way retiring from such relationships. In honesty, Halliday confesses that 'I have always made it clear that the most important influence on my own thinking came from my teacher J. R. Firth. It is from Firth, of course, that the concept of 'system' is derived, from which systemic theory gets its name... the system in this sense is found only in Firth's theoretical framework' (Halliday, 1985, p. 2). Halliday does not only see Firth as his teacher (perhaps, there were so many teachers of Halliday while a student of language); he places premium on the influences of Firth in both his thoughts and the title of his theoretical model, SFT. Firth remains a reckoning force that propels the dynamo of the Hallidayan grammatics to an extent of naming it after Firth's systemic orientation. Firthianism, Halliday affirms, is the spark and the greatest influence of SFT. One of the arguments of Firth is that language is a system of systems and must be seen as a polysystemic activity (Bloor \& Bloor, 2004). Of course, the theory receives influences from many other scholars. Some of them are Firth's colleagues while some are his track-mates (using Halliday's own word). The heat of Malinowskianism is felt in SFT through the concept of Context of Situation. This Malinowskian term is integrated into SFT as a contextual ornament that projects SFT as socio-semiotics. Malinowski suggests that no language should be seen as been primitive for every language is primarily a facility for getting things done. This is owing to the fact that language derives meanings from the events and situations of its functional operations (ibid.). The contextual theory is originally Malinowski's. 
SFT also identifies with the celebrated prestigious constructs of the Prague School through the ideas of so many scholars including Jakobson as well as Bühler (Halliday, 1994; Bloor \& Bloor, 2013). Jakobson proposes six distinct functions of language communications as referential, emotive, conative, phatic, metalingual, and poetic (Jaworski \& Coupland, 2006, p. 51). Halliday constructs four speech roles of giving information, demanding information, giving goods-\&services, demanding goods-\&-services from Jakobsonianism regarding communication ethos. The Jakobian communication functions redesigned are further labeled as statement, question, offer and command. SFT recognizes these grammatical elements in linguistic/clausal analysis (Thompson, 2004, p. 46-7). Apart from the propositions of Jakobson, Bühler, also of the Prague School emphasizes the functional model of language once again as expressive, conative and referential. It is from the Bühler's model that Halliday generates his Ideational, Interpersonal and Textual Metafunctions. Happily enough, the three metafunctions serve as the core domain in which the substances of SFT are developed, established and interconnected (Halliday, 1978, p. 48). So, the speech functional roles and the triadic metafunctions in SFT are Jakobian and Bühlerian proportional adaptations.

Another renowned concept in SFT is register. It was Ellis Jeffrey, according to Halliday, that attempted to explore the unknown terrain of linguistics and Denis Berg worked on conceptual-functional grammar. It was in that quest and along the line that Jean Ure was incited to introduce the notion of register and developed it into a systemic framework to teach foreign language learners (Halliday, 1985, p. 4). We have highlighted five areas of influence that Halliday's linguistic parents have on SFT. These can be recapped as system (polysystemic), contextualization, and verbal communications. Others are functions of language and register. In addition, Halliday adopts the concepts of Syntangmatic Order and Paradigmatic Order from Saussurean thoughts (De Beaugrande, 1991, p. 24), Discourse from Zellig Harris (Malmkjear, 2004, p. 115) and Theme from Mathesius of the Prague School (Rashidi, 1992, p. 189). What has Halliday done to propound a robust and comprehensive theory that takes care of textual analysis of language in a wider dimension (to an extent)?

The writer sees Halliday as a great linguist who takes his time to understand the thoughts of other scholars on language. He approaches that through observation of their ideas, identification of the relevant parts of their thoughts, and collation of those relevant thoughts together as a wholesome entity. Halliday further develops those scholarly thoughts by injecting his perspectives - very distinctive - on them in order to propound a single theoretical model. That unique model takes care of linguists' yearnings to an extent. SFT is a theoretical mechanism that one submits to as abiding by the Lakatos Principle of hard-core. The hard-core refers to useful conceptual elements of an earlier theory which must be protected and referenced for its relevance in the social system. It becomes an unwise behavior to refute hard-core in modifying or reviewing the concept for developmental purposes (Ndubuisi, 1998, p. 321-2). The inspiring action of Halliday persuades Hudson (1996, p. 63) to courageously say that 'Halliday aims better than some of us.' Halliday's SFT seems a theoretical factor of unification in linguistic analytical realms because it aims at focusing text; 
however, it has been drawn into pictorial, imagery and socio-cognitive applications (e.g. O'Toole, 1994; Thompson, 2014).

\section{SFT: Three Metafunctions}

When an individual comments that a theory is different from others; the person refers in earnest to the theory's significant point of reference. Apart from the SFT's focus on the relationship that occurs between language and elements of the social strata the concept of system is very germane (Fairclough, 2003; Chappell, 2013; Sugeng, 2014). It is not only the peculiarity of system that distinguishes SFT from other theories but its distinction lies greatly in the development of language structures into system networks. System and system networks are novel devices that serve as its point of departure. There is, so to say, a paradigm shift from appreciating language from its horizontal arrangement (Syntagmatic) to its vertical organization (paradigmatic). Eggins (2004, p. 193) recognizes the distinction when she argues that 'formal grammatical approaches tend to prioritize the description of Syntagmatic relations, while functional grammatical approaches tend to prioritize the description of paradigmatic relations'. Approaching language from a syntagmatic observation is to examine its syntactic structures from left to right - lexicogrammatical sequence - as linguistic rules permit the analyst. The agreement is to demonstrate the constituents of language that operate together in order to construct a functional paradigm. In contrast, the paradigmatic approach - the domain of SFT - reveals the alternative structures in a system of language in terms of choice.

In communicative interaction (i.e. clause process), choices are made from all other lexemes available to the language user. After the clause has become a product, it could also have been realized with alternative lexemes - in terms of synonyms, pronominalization, mood, markedness, polarity, tense, voice, etc. Realizing a clause from a paradigmatic formation is an act of producing opposing choices to achieve a textual organization. Halliday and Matthiessen describe paradigmatic order as 'what goes instead of what' and Syntagmatic approach as 'what goes together with what' (2004, p. 22). In these perspectives, System is paradigmatic while Structure is Syntagmatic. In addition to that, system is appreciated through delicacy and structure is realized through grammatical ranks. Delicacy functions as 'a kind of a kind of...' while rank operates as 'a part of a part of...' (ibid.). The lexemic structures of delicacy connect one another/each other as lexemes of the rank of a clause are entwined to produce meaning potential. The three metafunctions are the 'tangent' that deviates SFT from the usual linguistic circumference of analysis.

Ideational, Interpersonal and Textual Metafunctions are not only distinct as the crux of SFT; they are also meaning potential facilities. They are fascinating tools of textual explorations. Metafunctions are a priesthood of meaning custodians in linguistic structures. The invaluable element in Ideational Metafunction is the goings-on. The metafunction provides an answer to the whole lots of goings-on in the world (internal and external). It indicates how 'what is being' in the world is represented (Halliday \& Matthiessen, 2014, p. 211-223). Three elements are operational in a clause to depict this. They are process, 
participant(s) and circumstance. The process is the core of transitivity. Participant is the elements - animate or inanimate - that are involved in the clausal event. Circumstance provides additional information, that is, 'background information' to the transitivity system. It is an augmentation device. Halliday (1994), and Halliday and Matthiessen (2014) identify six processes in English - material, mental, relational, behavioral, verbal and existential - with variations of participants as shown in Figure 1 below.

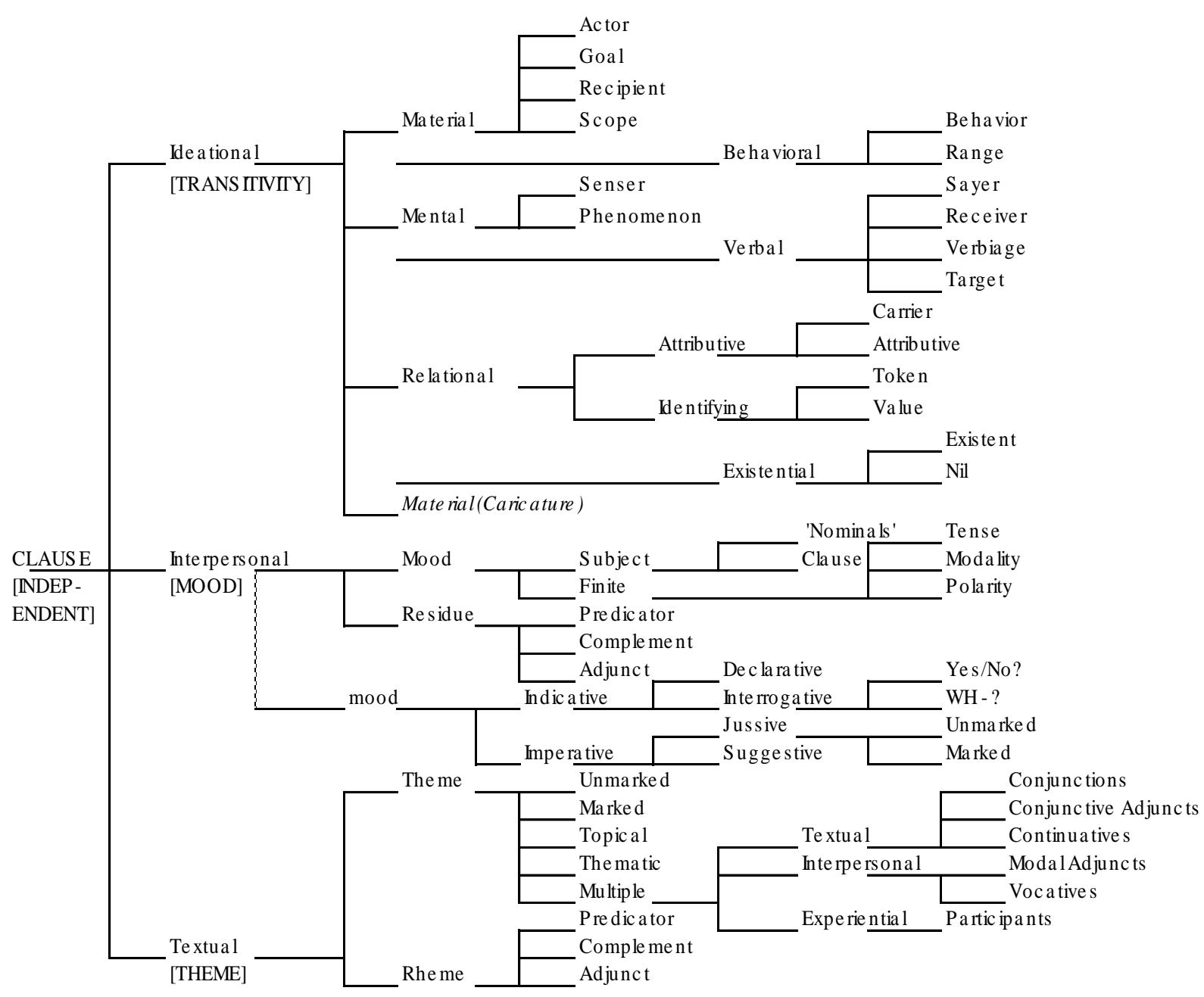

Fig ure 1: Three Me tafunctions' Composite System Ne twork

As the participants of each process vary so also are different circumstantial structures in the transitivity system. Circumstantials are mobile. They have the liberty to operate in any part of the clause - as a peak of prominence, at the middle or at the end. The encoder at his autonomy determines circumstantial functional positions of clauses (valuable sources include Ravelli, 2000; Eggins, 2004; Martin, 2016).

The purpose of using language as a communicative instrument is for interaction. The interaction builds a relationship in turn between the interactants. There is an act of speaking called interact. Thompson (2014) articulates that 
language constructs interpersonal meaning of role playing and relationship building between speaker/writer and listener/reader. In this course, people use language to express their thoughts, beliefs, establish facts, influence the decision of others, etc. Mood is the nucleus of Interpersonal Metafunction which realizes Subject and Finite. Besides, Halliday (1994) asserts that there are four mood semantic resources in English, as earlier mentioned, they are, giving or demanding (goods-\&-service) and giving and demanding (information). Giving and demanding goods-\&-services are functionally ancillary while giving and demanding pieces of information perform constitutive functions (Thompson, 2004, p. 46-7; Bednarek, 2010). The remaining portion of the clause is Residue.

The encoder of a clause organizes it as the individual wants in order for an interaction to take place and goings-on represented. This arrangement brings about textual meaning. Structural meaning is realized in Theme. The Theme reveals the structural part that foregrounds the message. Several points of view emanate in order to describe the Theme of a clause in English. Theme has been regarded as the essential ideational jumping-off point (Rashidi, 1992, p. 192), the background and first position of the clause (Ravelli, 2000, p. 52; Fontaine, 2013, p. 139-146), and the point of departure that locates and orients the content (Halliday \& Matthiessen, 2014, p. 88-98). One can also appreciate Theme as a universally obligatory element that enables a clause to function as message. It is also referred to as a psychological notion that arbitrarily takes the speaker's/writer's point of view. The Theme is a single constituent (and sometimes multiple e.g. multiple Themes that appear in form of ideational, interpersonal and textual elements) that occurs at the initial position of a clause. The other part of the clause as a message is the Rheme. The Rheme expresses the hub of the message of the encoder (details about Theme are in Rashidi, 1992; Berry, 1996; Thompson, 2014).

Figure 1 displays composite system network of the Halliday's metafunctions as the meaning representative of an independent clause. It demonstrates the ideational metafunction with material, mental and relational processes (major); and behavioral, verbal and existential processes (minor). The interpersonal metafunction contains two moods; Mood as the Subject and Finite, and mood as grammatical structures of indicative and imperative. The textual metafunction contains Theme with its forms as unmarked, marked, etc. and Rheme with predicator, complement, etc. The applications of Ideational, Interpersonal and Textual Metafunctions have been done to the textual structures of the advertising frame of Premium Pension Limited (PPL). This is meant to demonstrate the functional and potential meanings in the independent clauses of the ad.

\section{Methodology}

The author selected an ad of PPL from The Punch newspaper to illustrate the influence of SFT on the advertising text. The three metafunctions - Ideational, Interpersonal and Textual - are facilities of processing the texts. After the analysis, the six clauses were juxtaposed with the assistance of statistical tools of table and graph as a means of demonstrating the degree of the metafunctional recurrence. The semiotic slots created by SFT concepts permitted the application 
of the statistical measurements these are indicators of the viability of SFT on the reading of a text in terms of value generation and accountability. The discussion addresses the individual clause in both structural and systemic ways.

\section{Data Presentation}

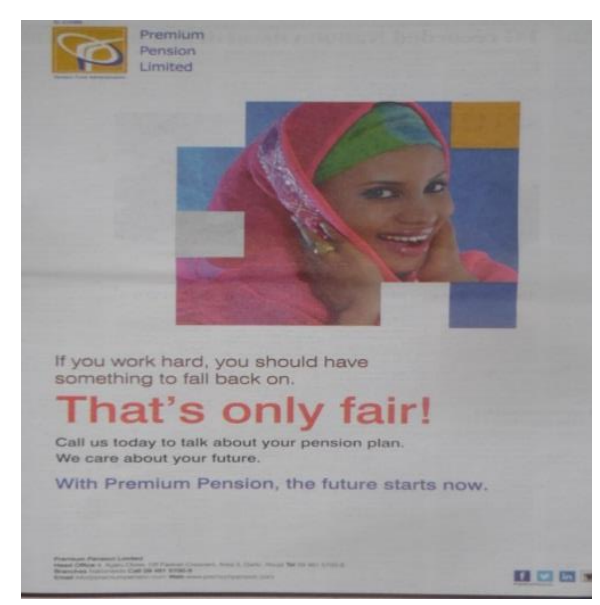

Figure 2: PPL ad

\section{Data Analysis}

\begin{tabular}{l|l|l|l|l|}
\cline { 2 - 5 }$T X .1$ & If & you & work & hard \\
ID: & Actor & Proc:Material & Goal \\
\cline { 2 - 5 } INT: & Conj. & Subject & Fin:Presen Work:Predicator & Complmt. \\
\cline { 2 - 5 } & & Mood & \multicolumn{2}{|c|}{ Residue } \\
\cline { 2 - 5 } TEX: Theme1 & Theme2 & Rheme & \multicolumn{2}{l}{} \\
\cline { 2 - 5 }
\end{tabular}

\begin{tabular}{|c|c|c|c|c|c|}
\hline$T X .2$ & you & should & have & something & to fall back on \\
\hline ID: & Token & \multicolumn{2}{|c|}{ Proc:Rel., Ident. } & Value & Circum:Location,Place \\
\hline \multirow[t]{3}{*}{ INT: } & Subject & Finite & Predicator & Complmt. & Adjuct \\
\hline & \multicolumn{2}{|l|}{ Mood } & \multicolumn{3}{|l|}{ Residue } \\
\hline & Theme & Rheme & & & \\
\hline
\end{tabular}

\begin{tabular}{l|l|l|l|l|} 
TX.3 & That & 's & only & fair! \\
\cline { 2 - 4 } ID: & Carrier & Rel:Attrib. & Attributive \\
\cline { 2 - 4 } INT: & Subject & Finite & Mod.Adjunct & Complmt. \\
\cline { 2 - 3 } & Mood & Residue \\
\cline { 2 - 3 } & Theme & Rheme & \\
\cline { 2 - 3 }
\end{tabular}




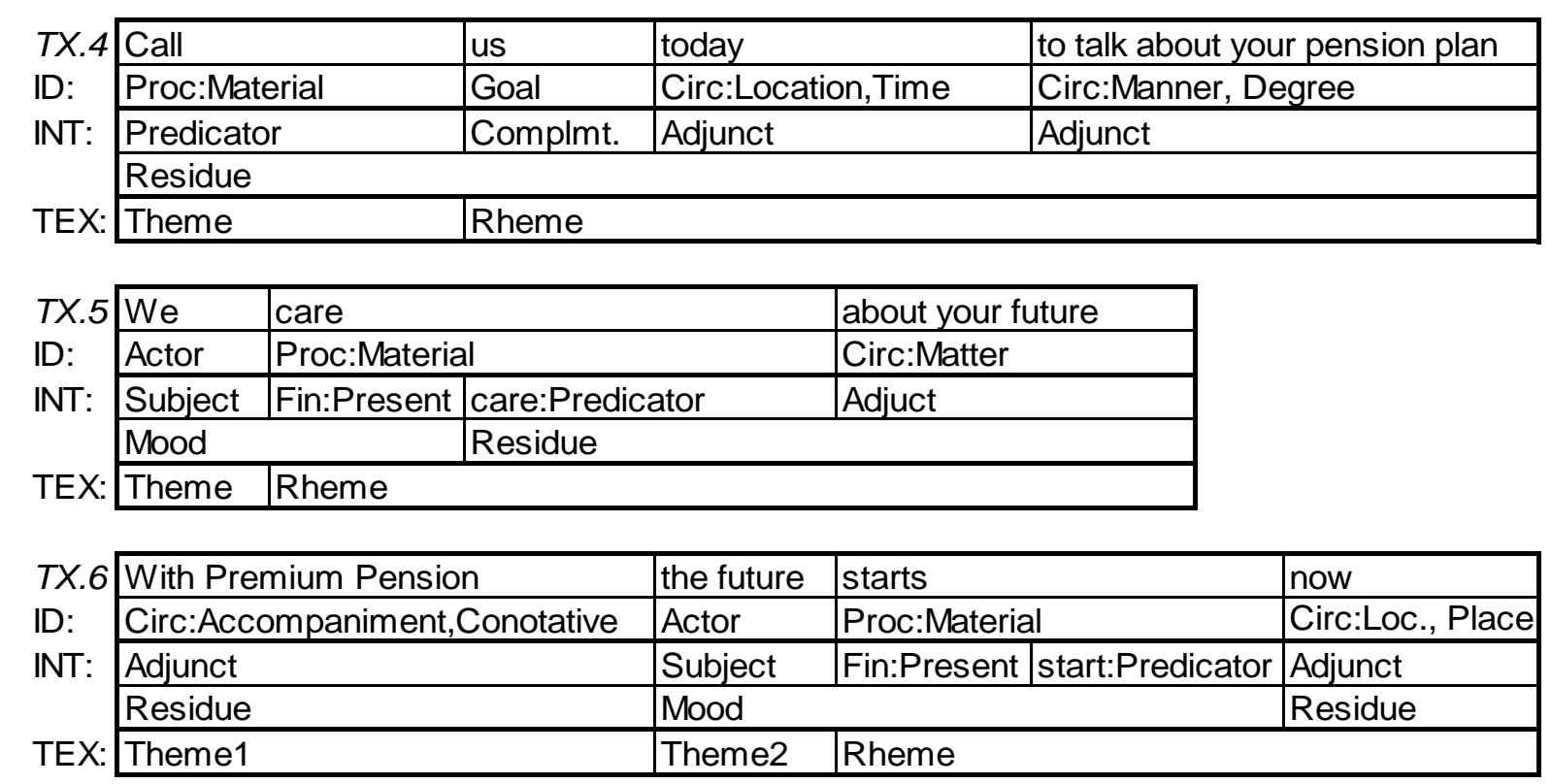

Figure 3: A composite analysis of the six clauses in the PPL ad plate

Figure 3 represents the six clauses operating in the semiotic slots assigned to them. These are observed in TX.1 - TX.6. The analysis shows the clauses in two perspectives. First, their structural organization is from left to right which is the breaking down of the lexicogrammatical constituents into segments. Second, the shredding of the metafunctions from the ideational (Actor) through to the interpersonal (Subject) and to textual (Theme) demonstrates a systemic analysis of each clause in the ad plate. A combination of the three systemic analyses provides meaning potential of the clause structure.

\section{Results}

Tables 1, 2, and 3 below show the systemic analyses of the text of PPL. The calibrations become necessity in order to expose the influence of SFT on the chosen data to the audience.

\begin{tabular}{|l|c|c|c|c|c|c|c|}
\hline Semiotic Slot & TX1 & TX2 & TX3 & TX4 & TX5 & TX6 & Total \\
\hline Material & 1 & 0 & 0 & 1 & 1 & 1 & 4 \\
\hline Mental & 0 & 0 & 0 & 0 & 0 & 0 & 0 \\
\hline Relational & 0 & 1 & 1 & 0 & 0 & 0 & 2 \\
\hline Behavioral & 0 & 0 & 0 & 0 & 0 & 0 & 0 \\
\hline Verbal & 0 & 0 & 0 & 0 & 0 & 0 & 0 \\
\hline Existential & 0 & 0 & 0 & 0 & 0 & 0 & 0 \\
\hline Circumstantial & 0 & 1 & 0 & 2 & 1 & 2 & 6 \\
\hline
\end{tabular}

Table 1: The value of Ideational Metafunction in the PPL ad 


\begin{tabular}{|l|c|c|c|c|c|c|c|}
\hline Semiotic Slot & TX1 & TX2 & TX3 & TX4 & TX5 & TX6 & Total \\
\hline Subject & 1 & 1 & 1 & 0 & 1 & 1 & 5 \\
\hline Finite & 1 & 1 & 1 & 0 & 1 & 1 & 5 \\
\hline Predicator & 1 & 1 & 0 & 1 & 1 & 1 & 5 \\
\hline Complement & 1 & 1 & 1 & 1 & 0 & 0 & 4 \\
\hline Adjunct & 0 & 1 & 1 & 2 & 1 & 2 & 7 \\
\hline
\end{tabular}

Table 2: The value of Interpersonal Metafunction in the PPL ad.

\begin{tabular}{|l|c|c|c|c|c|c|c|}
\hline Semiotic Slot & TX1 & TX2 & TX3 & TX4 & TX5 & TX6 & Total \\
\hline Theme 1 & 1 & 1 & 1 & 1 & 1 & 1 & 6 \\
\hline Theme 2 & 1 & 0 & 0 & 0 & 0 & 1 & 2 \\
\hline Theme 3 & 0 & 0 & 0 & 0 & 0 & 0 & 0 \\
\hline Rheme & 1 & 1 & 1 & 1 & 1 & 1 & 6 \\
\hline
\end{tabular}

Table 3: The value of Textual Metafunction in the PPL ad.

Table 4 below demonstrates the cumulative of the three metafunctions as a composite tool of analyzing the clauses of the PPL ad.

\begin{tabular}{|c|c|c|c|c|c|c|c|c|c|c|c|c|c|c|c|c|}
\hline \multirow[t]{2}{*}{ Metafunctions } & \multicolumn{16}{|c|}{ Semiotic Slot } \\
\hline & Mat & Men & Rel & Beh & Ver & Ext & Cir & $\mathrm{S}$ & $\mathrm{F}$ & $\mathrm{P}$ & C & A & Th1 & Th2 & Th3 & Rhe \\
\hline Ideational & 4 & 0 & 2 & 0 & 0 & 0 & 6 & 0 & 0 & 0 & 0 & 0 & 0 & 0 & 0 & 0 \\
\hline Interpersonal & 0 & 0 & 0 & 0 & 0 & 0 & 0 & 0 & 5 & 5 & 5 & 4 & 7 & 0 & 0 & 0 \\
\hline Textual & 0 & 0 & 0 & 0 & 0 & 0 & 0 & 0 & 0 & 0 & 0 & 0 & 6 & 2 & 0 & 6 \\
\hline
\end{tabular}

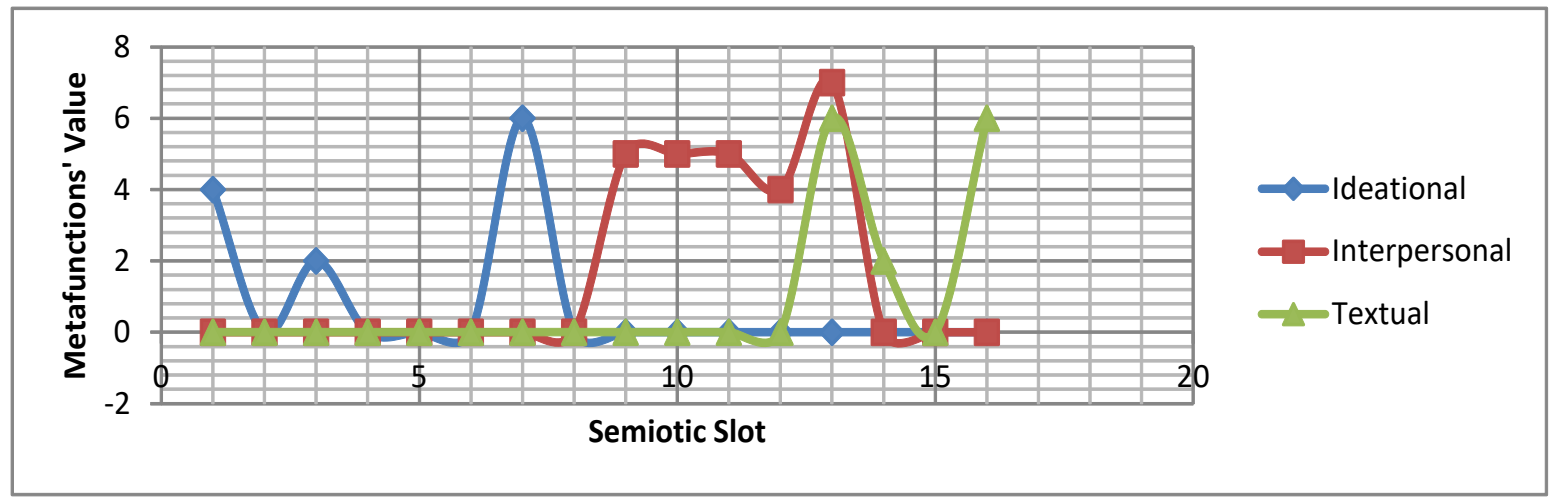

Figure 4: Cumulative value of the three metafunctions in PPL ad.

The Ideational Metafunction in Figure 4 reveals that only two processes of Material and Relational function in the text of PPL ad. The material process records the highest point. Adjunct in the Interpersonal Metafunction operates more than any other structures despite that it is not totally part of the interact. Subject and Finite that occupy the mood (interact) domain function five times in TX.1-5. TX.6 does not have mood at all. By average, this characterizes the residue as operating more in the PPL ad because both Predicator and Complement operate in five and four times respectively. Apart from Theme 2 that 
recurs twice in the text, one could have argued that the text does not deploy more of multiple themes. Theme 1 functions in all the clauses as well as Rheme. Therefore, the systemic point of unification can be classified as participants and process (Ideational), subject and finite (Interpersonal), and theme (textual). Explanations and implications of the structure-system relationships are further portrayed in the discussion subdivision.

\section{Discussion}

The structure of the clause in TX.1 is a conditional statement that states, If you work hard. The systemic analysis shows that If is not relevant in ideational meaning. However, it is a conjunction in interpersonal meaning and Theme1 in textual meaning respectively. It means that the meanings that the transitivity system cannot produce are realized both in mood and thematic systems. The semiotic slots of ID, INT., and TEX. realize you as Actor, Subject and Theme2. These serve as alternative meanings, yet, composite to the lexeme, you. The process, work is a material process which the mood system explains as being a present Finite and at the same time a predicator for work. It is a fused component. The Subject, you and Finite, present, represent the Mood of INT. The synthetic fusion of work provides an opportunity for INT. to divide it into two parts. The other part of it shows work as predicator. The other participant of the material process, work, is Goal which explains the inanimate object of the transitivity system, whereas, hard is complement in interpersonal meaning. The thematic structure reveals work hard as the Rheme that contains the core meaning of the clause.

From a contextual notion, the ideational meaning is the Field of discourse, interpersonal meaning is the Tenor of discourse and textual meaning is the Mode of discourse (Haratyan, 2011). The going-on is about the ability to work hard which the advertiser (Premium Pension manager) characterizes as profitable and beneficial. The clause is presented in a present form to sensitize the public about the mission of the ad to easily excite them for compliance. The pronoun you as a second person plural refers to the entire people engaging in one form of endeavor or another to better their lives. The idea of conditionality is a persuasive strategy to make the recipients of the ad thinks deeply for a crucial decision about unanticipated future challenges. You functions as Token, Subject and Theme in the systemic analysis which is dissimilar to TX.1 due to the nature of its process. The structure you should have something to fall back on, has should have as the relational process for the purpose of identification, Value is the other participant that is accompanied with a background element, to fall back on. The circumstantial locates a place for the public in the transitivity system. Linking the ideational meaning to the interpersonal meaning, the system reveals that the process, should have, is divided into Finite and Predicator. Something complements the structure with an Adjunct to fall back on. It shows further that you should is the Mood, while all the other elements are Residue. The textual meaning demonstrates you as Theme and should have something to fall back on as Rheme.

The goings-on, should have, connects the workers who are the focus of the ad to the duration at which people have been working. As mentioned in TX.1, their hard work is supposed to provide economic leverage for them. So, the 
condition that will give them rest is hard labor. If such a condition is met, there is a brighter future for workers. The target of the ad is to stimulate workers to think about tomorrow when they will retire and, perhaps, there will be no enough strength to work. Whatever money that PPL has assisted them to keep will be their gains in the nearest future. The modality, should, puts pressure on the public in order to weigh their financial strengths. The examination of self-worth can determine their actions towards the Premium Plan product on sale. In the pension plan ad, advertiser is the giver and the public are the receivers of the message. The relationship is that of a seller and a buyer. In a way the pension plan professionals persuade the public in order to build a lasting, or seemingly, permanent relationship with them. This could be the cause for referring to the future.

The clause in TX.3, that is, That's only fair!, is anaphoric in substance. It refers to the message that its discourse antecedent, if you work hard you should have something to fall back on, delivers. This is demonstrated through the lexeme, that. That is Carrier in ideational meaning, Subject in interpersonal meaning and Theme in textual meaning. The process 's is attributive because it relates an event of the past to another reality shown as fair. As the Finite of the clause, 's, does not perform any action but rather relates what takes place between Carrier and Attributive together. One observes the symbolic organization thus: Theme = That and Rheme = 's only fair! The source of all the clauses is the ad plates. This makes them written discourse. However, the persuasive stimulant is judgmental propagated through the word fair!

There is neither Actor nor Mood in the systemic analysis of TX.4, except that the Theme for it is an imperative clause. Despite that, the material process, call, indicates as Goal which follows with to talk about your pension plan as the Circumstance. By extension, the Circumstance contains a mental process, to talk about. The circumstantial enhances the manner of degree of the pension plan intended to be sold to the public. The interrelationship of the three clauses before it cannot be undermined. The clause is a pointer to the reason for the ad. It also reveals the direction that PPL wants the public to go. The public are sensified to call the pension administrator in order to discuss the benefits of the product and buying possibility. The command, Call us today, is placed on the premium of time. The time to act is now. The ad gives no room for procrastination. It will be a surprise for textual element of an ad to appear without an element of command. Command is a trait of advertising (Myers, 1994). Previous clauses in TX 1,2, and 3 have been placed as being conditional, sensitizational and judgmental. This clause, call us today to talk about your pension plan is adopted to summarize the purpose intended. The intention of the ad is to influence the people to buy the pension plan. It is presented as a solution to the future financial challenge of the people whereas the buying of the pension plan will enhance growth and development of PPL.

The structure of TX.5 is We care about your future. As usual, the description of its systemic relation covers ID., INT., and TEX. We functions in the transitivity system as Actor for its process, care, is material. In the mood system, it operates as Subject which has its Finite in the tense of present. In the thematic system, $W e$ is Theme and the rest of the clause, care about your future, performs the 
rhematic function. Besides, the transitivity system contains a circumstantial, about your future, that points to the audience the background detail of the system. About your future projects what the clause is all about, that is, the raison d'être for featuring it as Matter. In an alternative model, about your future is adjunct in the mood system that has care as predicator. The meaning potential of the structure is described according to the semiotic space earmarked for We care about your future in the systemic columns. By implication, We care about your future addresses the public as a collective voice of a team of professionals. The first person plural, We, is a proof of that assertion. The clause connects PPL performance to the recipients through the workforce.

The adoption of the lexeme, care, demonstrates the concern of PPL and its workforce for the target audience who submit to the dictate of the ad. The firm presents itself as an enterprise that has great interest in the future wellbeing of the clients. The workforce is a team of professionals who are watchdogs of the financial statuses of customers and are ready to treat them as kings. In a succinct way, the author can argue that looking after the welfare of customers seems the responsibility and concern of PPL as well as its team of professionals. Putting the future on the pipeline is a strategy adopted to remind the public about the importance of their later time. It sensitizes the readers to remember their old age, and prepare for it as much as they can. Perhaps, many institutions advertise to influence consumers about their present needs, and most consumers also think deeply about their immediate need. However, PPL maintains its stand by drawing people's attention to, and be mindful of their future needs. The future is portrayed as more important than the way that so many people might view it.

TX.6 is a subordinate to TX.5 because it provides a support for TX.5. The continuity is projected in the Actor, the future. As TX.5 focuses the future so also is TX.6. The structure, With Premium Pension, the future starts now, begins its point of reference with a circumstantial - With Premium Pension. It also ends with another circumstantial element - now. These function as adjuncts in the mood system whereas they are labeled as Theme 1 and part of Rheme in the thematic system. Transitivity views With premium pension as conative accompanying device that extends the message of the clause. Now indicates the location that is referred to in form of time. From the ideational perspective, starts is a material process that illustrates the beginning of how to save the future of the recipients of the ad. The other opposing relation is the interpersonal meaning which explains starts as Finite in the present tense and at the same time as a predicator (i.e. predicated start).

Significantly, With Premium Pension, the future starts now, concludes the message of the ad. The ad points to PPL as the arbiter (the lender of last result) of the future of the people. PPL shows that the challenge that people will face after their retirement is its sole responsibility and upkeep. The future of the people as the centerpiece is propagated as beginning from this moment. The structure, starts now, is an attempt to persuade recipients of the ad in order to patronize the service campaigned to them. The expectation is that, they should be saving money with PPL for the purpose of future usages. Meanwhile, people are not provided with any alternatives outside of PPL. That is the grounds for making With Premium Pension the point of departure of the message. 


\section{Conclusion}

The study has addressed the six clauses in the ad of PPL from its systemic domains of Ideational, Interpersonal and Textual meanings. The spheres produce discourse potential for the message of the clause. The message rests on three important standpoints. In the first instance, the ad places a condition before the public in which their future is anchored. It enthuses the public to take a decision that will favor PPL. And it serves as a justification for hard work. The second instance is the heart of the message that sensitizes people once again to launch actions. People are commanded to call the PPL professionals so that their future can be discussed on the modus operand of its financial security. Obedience to the clarion call is a partnership that can only work between the advertiser and the public. However, it is a relationship that can increase the financial propensity of PPL in a way bearing in mind that pension funds are not easily released to pensioners at a request. After the people have been propelled to act, the third phase focuses the condescending attitude of PPL. This is propagated as caring. Caring seems the self-appraisal and self-worth of PPL and its professionals. It assures the recipients of trusted integrity projected as kindness that is consistently maintained in the firm. Moreover, SFT reveals the ad's textual analysis through transitivity, mood and thematic systems. The operation permits scientific devices - table and graph - to assist the study in interpreting texts in numerical values. These are further elucidated in discourse processes for appropriate meaning potential. It is the hope of the author that SFT's three metafunctions will further be applied to texts in different dimensions for meaning generations.

\section{References}

Bednarek, M. (2010). Corpus Linguistics and Systemic Functional Linguistics: Interpersonal Meaning, Identity and Bonding in Popular Culture. In M. Bednarek, \& J. R. Martin (Eds.), New discourse on language: Functional perspectives on multimodality, identity, and affiliation, 237-266. London: Continuum.

Bloor, T., \& Bloor, M. (2004). The functional analysis of English. Great Britain: Hodder

Bloor, T., \& Bloor, M. (2013). The functional analysis of English. Abingdon, Oxon: Routledge.

Berry, M. (1996). What is Theme? A(nother) Perspective. In C. Butler, R. Fawcett, \& G. Huang (Eds.), Meaning and form: Systemic functional interpretations, LVII, (pp.164). Ablex: Norwood, New Jersey.

Berry, M., Butler, C., Fawcett, R., \& Huang, G. (1996) (Eds.). Meaning and form: Systemic functional interpretations, LVII, (pp. xi-xv). Ablex: Norwood, New Jersey.

Chomsky, N. (1972). Language and mind. Harcourt, Brace: Jovanovich.

Christie, F., \& Unsworth, L. (2000). Developing socially responsible language research. In L. Unsworth (Ed.), Researching language in schools and communities, I, (1- 26). London: Continuum.

Cross, M. (1992). Choice in lexis: Computer generation of lexis as most delicate grammar. Language Sciences 14(4). 579-605. DOI: 10.1016/03880001(92)90031-9. 
Daramola, A. (2008). A child of necessity: An analysis of political discourse in Nigeria. Pragmatics: Quarterly publication of the International Pragmatics Association, 18(3), 355-360.

De Beaugrande, R. (1991). Linguistic theory: The discourse of fundamental works. London and New York: Longman.

Eggins, S. (2004). Introduction to systemic functional linguistics. London: Continuum.

Eggins, S., \& Slade, D. (1997). Analyzing casual conversation. London: Equinox.

Fairclough, N. (2003). Analysing discourse: Textual analysis for social research. New York: Routledge.

Fawcett, R. P. (1988). What makes a good system network good? - Four pairs of concepts for such evaluation. In J. Benson, \& W. Greaves (Eds.), Systemic functional approaches to discourse XXVI (pp. 1-28). Norwood, New Jersey: Ablex Publishing Corporation.

Fontaine, L. (2013). Analyzing English grammar: A systemic functional introduction. Cambridge: Cambridge University Press.

Halliday, M. A. K. (1978). Language as social semiotic: The social interpretation of language and meaning. London: Edward Arnold.

Halliday, M. A. K. (1985). Systemic background. In J. Benson, \& M. Greaves (Eds.), Systemic perspectives on discourse XV, (PP. 1-15). Norwood, New Jersey: Ablex Publishing Corporation.

Halliday, M. A. K. (1994). An Introduction to functional grammar. Great Britain: Arnold.

Halliday, M. A. K., \& Matthiessen M. I. M. (2004). An introduction to functional grammar. Great Britain.

Halliday, M. A. K. (2014). Halliday's introduction to functional grammar. Abingdon, Oxon: Routledge.

Hudson, R. A. (1996). Sociolinguistics. Cambridge: Cambridge University Press.

Jaworski, A., \& Coupland, N. (2006). The discourse reader. New York: Routledge.

Kasper, R. (1988). Systemic grammar and functional unification grammar. In J. Benson, \& W. Greaves (Eds.), Systemic functional approaches to discourse $\quad$ XXVI, (pp. 176-199). Norwood, New Jersey: Ablex Publishing Corporation.

Kress, G. R., \& van Leeuwen, T. (1996). Reading images: The grammar of visual design. London \& New York: Routledge.

Leech, G. (1966). English in advertising: A linguistic study of advertising in Great Britain. London: Longman.

Lemke, J. (1995). Textual politics: Discourse and social dynamics. Oxon: Taylor \& Francis.

Malmkjaer, K. (2004) (Ed.). The linguistics encydopedia. London: Routledge.

Martin, J. R. (2016). Meaning matters: A short history of systemic functional linguistics. Word 62, 1, 35-58.

Matthiessen, C. (1995). Lexicogrammatical cartography: English systems. Tokyo: International Language Sciences Publishers.

McDonald, E. (1994). Completive verb compounds in Modern Chinese: a new look at an old problem. Journal of Chinese Linguistics, 22(2), 317-362.

McGregor, W. (1990). A functional grammar of Gooniyandi. Amsterdam: Benjamins.

Mwinlaaru, I. N., \& Xuan, W. W. (2016). A survey of studies in systemic functional language description and typology. Functional Linguistics 3(8), 1-42. DOI: 10.1186/s40554-016-0030-4.

Myers, G. (1994). Words in ad. London: Arnold.

Ndubuisi, F. N. (1998). Common features of science. In J. Unah (1998). Philosophy for all disciplines, (pp. 316 - 328). Bariga: Panaf Press.

O'Toole, M. (1994). The language of displayed art. London: Pinter (Leicester University Press). 
Rashidi, L. S. (1992). Towards an understanding of the notion of theme: An example from Dari. In M. Davies, \& L. Ravelli (Eds.), Advances in systemic linguistics, recent theory and practice, $189-204$.

Ravelli, L. (2000). 'Getting started with functional analysis of texts'. In L. Unsworth (Ed.), Researching Language in schools and communities (pp. $1-26)$. London: Cassell.

Thompson, G. (2004). Introducing functional grammar. Great Britain: Hodder Arnold.

Thompson, G. (2014). Introducing functional grammar. Abingdon, Oxon: Routledge.

\section{Internet Resources}

Matthiessen, C., \& Halliday, M. (1997). Systemic functional grammar: A first step into the theory. Retrieved on $12^{\text {th }}$ September, 2010 from http://web.uam.es/departamentos/filoyletras/filoinglesa/Courses/LFCSFL/FirstStep.html.

Sugeng, H. (2014). Introduction to systemic functional grammar. Retrieved on $16^{\text {th }}$ January 2017 from http://www.slideshare.net/sugengha/systemic-functionalgrammar-32377493.

Haratyan, F. (2011). Halliday's SFL and social meaning. 2nd International Conference on Humanities, Historical and Social Sciences IPEDR, 17. Singapore: IACSIT Press. Retrieved on $19^{\text {th }}$ January 2017 from http://www.ipedr.com/vol17/49CHHSS\%202011-H10074.pdf.

Olivares, B. E. (2013). The interpersonal and experiential grammar of Chilean Spanish: Towards a principled Systemic-Functional description based on axial argumentation. Retrieved on $26^{\text {th }}$ January 2017 from http://www.isfla.org/Systemics/Print/Theses/BQuiroz 2013.pdf.

James, R, M. (2014). Evolving systemic functional linguistics: Beyond the clause. Retrieved on $2^{\text {nd }}$ February 2017 from http://download.springer.com/static/pdf/593

Chappell, P. (2013). An introduction to systemic functional grammar. Retrieved on $12^{\text {th }}$ February 2017 from https://hoprea.wordpress.com/2013/02/07/an-introduction-to-systemic-functionalgrammar-by-phil-chappell/. 